\title{
Editorial:
}

\section{Enhancing Education: Attending to the Four Commonplaces}

\author{
Julian Kitchen \\ Editor \\ Brock University
}

At all levels-elementary, secondary and tertiary-there is a need to constantly improve education. There is no formula, no magic bullet. Instead, educators strive to make a difference through intervention in one or more areas of the educational experience.

Joseph Schwab identified four commonplace of education-teacher, learner, curriculum, and milieu (Schwab, 1970) - that exist in all schools and in other learning contexts. The authors of each article in this issue of Brock Education address one or more commonplaces in their research and their efforts to improve education. Many also give explicit attention to social justice.

As teachers are the professionals who guide the educational experience in classrooms, many efforts to improve schooling focus on improving practice. In "Teachers' Perspectives on Educational Research," Karen Drill, Shazia Miller, and Ellen Behrstock-Sherratt address the widely acknowledged disconnect between practitioners and the findings of educational research. They present two related studies conducted with teachers in the Chicago area on how teachers make use of research. As a result of these findings, they identify ways in which research findings can be made more accessible and useful to busy practitioners.

Astrid Steele, in "Shifting Currents: STSE in Northern Ontario Schools," focuses on the practices of secondary science teachers in rural, resource-extraction-based communities in northern Ontario. She investigates the extent to which science teachers are implementing mandated curriculum on the impacts of science on society and environment. While Steele finds that most teachers are shifting in their attitudes, she notes a range of factors that make it difficult for teachers to effectively address the curriculum and adapt it to local contexts. Like Drill and her associates, Steele offers recommendations to help teachers become more effective in their use of information from experts and policy makers.

Steele's article is situated on the border between teachers and curriculum, with a focus on teachers as curriculum makers. Marius Boboc and R. D. Nordgren, in "Improving Urban Students' College Readiness as a Driver of High School Curriculum Enhancement," work on the border between curriculum and milieu. Recognizing that impovershed urban students often struggle at college, they researched the effectiveness of an instrument designed and validated to predict success of impoverished minority students in college. They probe deeply into the importance of curriculum that is relevant to the lives of students at both secondary and college levels. The plan of action offers a holistic approach to curriculum improvement that considers students's developmental levels and sequences of learning across a range of content and skills 
needed for college success. By doing so, they contribute to the improvement of outcomes for learners who are not always well served by schools or society.

At the centre of the learning experience is the student. Each student has particular learning needs. In "Pre-service Teachers' Self-Regulated Learning and their Developing Concepts of SRL," Dawn Buzza and Trina Allinotte begin with the recognition that each student has different abilities and skills. Of particular significance for Buzza and Allinotte, is the fact that the ability to self-regulate skills, behaviours, and beliefs differs greatly from learner to learner. As well as learning about pedagogy and curriculum, they argue, new teachers also need to become aware strategies for enhancing self-regulated learning in students. Their paper, by investigating teacher candidates' application of SRL in their field experiences, offers the possibility that teachers can better support students in becoming effective self-regulated learners.

Christina DeRoche, in "Loose Coupling and Inhabited Institutions: Inclusion Policy and Teacher Strategies," is also concerned with improving the student experience by improving their learning skills. Whereas Buzza and Allinotte's work applies to all students, DeRoche focuses on the particular needs of exceptional learners. Through participant observation and interviews with two teachers and an educational assistant, she studies how the framework of loose coupling and inhabited institution was used by these educators to actively negotiate curriculum and pedagogy by drawing on the personal and social resources of each special needs learner. She concludes with recommendations about employing loose coupling with exceptional learners, and how to support educators in doing this important work.

The final article, "Enhancing Conditions for Aboriginal Learners in Higher Education: The Experiences of Nishnawbe Aski Teacher Candidates in a Teacher Education Program" by Julian Kitchen and John Hodson, focuses on the milieu in which Aboriginal B.Ed. students are prepared. The authors, based on interviews with Aboriginal teacher candidates, identify ways in which a community-based program inadvertently complicated the process of becoming a teacher and making it more difficult. Listening to the voices of minority learners who struggle to succeed in the unfamiliar territory of educational institutions is an important first step in making these institutions more effective in serving the needs of all learners and communities.

Each article in this issue helps us understand one or more of the commonplaces of education. Taken together they offer insights into how to enhance the skills of teachers, adapt curriculum to the needs of students, address the learning skills of students, and improve the contexts in which students learn. By addressing these in our practice, we as educators can make a positive difference for all students, particularly those not well served by contemporary schools or by the societies in which we live.

\section{References}

Schwab, J. J. (1970). The practical: A language for curriculum. School Review, 78, 1-23. 